\title{
Standard setting and carrier differentiation at seaports
}

\author{
Christopher B. Clott $^{1 *} \mathbb{D}$, Bruce C. Hartman² and Robert Cannizzaro ${ }^{1}$
}

\author{
* Correspondence: \\ chrisclott@gmail.com \\ ${ }^{1}$ Global Business and Transport, \\ State University of New York, \\ Maritime College, Bronx, NY, USA \\ Full list of author information is \\ available at the end of the article
}

\begin{abstract}
The deployment of mega container ships with a capacity for 18,000 + TEU on major trade lanes is a recent trend within the ocean shipping industry. Larger ships pose multiple challenges to ports and hinterland connections as well as to the beneficial cargo owners. To achieve maximum utilization of their larger vessels, carriers have entered cooperative global alliances on predetermined routes, resulting in new discharge patterns at U.S. ports. These multi-partner networks involve several competing firms which voluntarily and interactively engage in service delivery. Container carriage is increasingly competitive, and requires continuing cost reductions. There is increasing evidence, however, that cargo shippers are less satisfied with the service their supply chains are receiving. Standardizing process performance through supply chain integration and removing inefficiency will be needed to stabilize the international shipping market, but the question remains how ocean carriers will be able differentiate themselves and create improved supply chain performance. This paper suggests an answer through a simple standard performance measurement model. We will suggest that old systems of carrier competition could evolve to greater cooperation and coordination between business competitors, a state sometimes called "coopetition", by development of standard setting processes for sharing information while retaining specific service delivery structures to provide differentiated value to customers.
\end{abstract}

Keywords: Ocean shipping, Alliances, Standardization, Supply chain integration, Ocean carrier differentiation

\section{Introduction}

"The need to confront the oversupply (of ships) has resulted in more frequent and wider cooperation of shipping lines on all routes, thus providing more and more homogenous services. A resulting challenge in the industry is the difficulty of service differentiation as container transport is a highly standardized transport service and shipping lines are rarely in a position to establish differentiation of services in terms of quality."

The United Nations Conference on Trade \& Development (UNCTAD) Review of Maritime Transport (2015), p.39

Cooperative agreements between shipping lines in the form of alliances to improve supply chain cost performance is a fundamental issue present in the industry. Excess vessel capacity, downward pressure on freight rates and continued uncertainty in world

(c) The Author(s). 2018 Open Access This article is distributed under the terms of the Creative Commons Attribution 4.0 International License (http://creativecommons.org/licenses/by/4.0/), which permits unrestricted use, distribution, and reproduction in any medium, provided you give appropriate credit to the original author(s) and the source, provide a link to the Creative Commons license, and indicate if changes were made. 
trade have put pressure on ocean shipping companies to expand shipping alliances despite poor reliability, declining customer satisfaction, and increased operational complexity. This is particularly the case in the trade lanes serving the United States where long distances from coastal ports to major inland locations involve complex and costly multimodal arrangements. Effective management of supply chains from port to hinterland points has become a key factor differentiating product and service offerings and gaining accessibility to global customers for competitive advantage.

There has been extensive previous research on the dynamics of global carrier alliances (Heaver et al., 2000; Panayides and Cullinane, 2002; Song and Panayides, 2002; Cariou, 2008; Panayides and Wiedmer; 2011; Lee and Song, 2016), alliance stability and efficiency (Midoro and Pitto, 2000), coordination mechanisms (Van der Horst and Van der Lugt, 2011), and information sharing. Port and terminal competition and cooperation strategies in response to alliance formation have been examined by Heaver et al., (2001); Song, (2003), and Lee and Lam, (2015). The role of port regionalization and competitiveness (Notteboom and Yap, 2012) in response to changing supply chain requirements as a result of carrier alliances points to the need for more sophisticated study of port-cluster connections (Lee and Song, 2016). While ocean carrier alliances have allowed carriers to rationalize resources and extend their reach on the major trade lanes, they have created operational challenges centered on port congestion, schedule reliability, and hinterland service integration (Franc and Van der Horst, 2010; Meng, 2016). This has been further exacerbated by a transition in U.S. ports from reliance on ocean carriers to provide container chassis to reliance on third parties to provide the chassis as is the norm in other parts of the world. Major ports and regulatory bodies in the U.S. have convened 'task forces' composed of industry experts to collaborate on solutions addressing port productivity and performance (NY/NJ Port Authority, 2015). At this writing there is concern regarding overcapacity that has led to a collapse in rates and cancellations of sailings by the major carriers.

Since one of the most important roles of ocean alliances is to provide value by offering breadth and depth of trade lane coverage that customers demand without having to supply all of capacity themselves, it is crucial to investigate how customers can perceive the value of such alliances. This paper examines the current status of alliances and how carriers can possibly differentiate their services using transparent standardization measures to create value in the global marketplace. We suggest a simple standard performance measurement model that could be used to benchmark service delivery. Old systems of carrier competition could evolve to greater cooperation and coordination with ports and downstream logistics partners by developing standard-setting processes for sharing information and classifying cargos for handling, while retaining specific service delivery structures to provide value to customers. This is not a new concept. Examples of port/carrier information sharing include common port boards (Haropa- between Le Havre, Rouen and Paris, France), single national port authorities (Transnet National Port Authority in South Africa) and multi-country (Northern Corridor dashboard linking the port of Mombasa, Kenya with markets in Kenya, Uganda, Rwanda and Burundi as well as southern Sudan and northern Tanzania). It can be shaped through public and private coordination (Notteboom and Rodrique, 2012). Cooperation in service standard-setting, abetted by transparent information flows, can allow segmented handling of cargo by 
service requirement instead of by contract, and improve reliability to the level required in each supply chain.

Supply chain integration (SCI) has been the subject of recent study (Tseng and Liao, 2015). It can be defined as cooperation between partners in transport chains to achieve the common goal of successful on time delivery. It views goods movement as systems whose overall performance for the customers and shippers at the ends is the criterion of interest. In theory, it insists that performance measures be based on the end-to-end performance rather than that of any part; the best overall result may require partner compromises anywhere within the long chain of handling.

Lam and Voorde (2011) examined ocean carriers' SCI efforts one level forward or back with upstream partners (shippers) and downstream partners (ports) to classify SCI by function (customer service, inventory, transportation, and order processing) and strategic scope or time horizon (strategic, tactical, and operational). But this is not a complete integration of entire supply chains. There seems to be a positive association between SCI cooperation and value-added logistics service performance among shippers and carriers. Integration among supply chain partners and customers can lead to enhanced performance improvement (Esper and Williams, 2003; Tseng and Liao, 2015).

Beneficial Cargo Owners (BCOs) are often represented by Ocean Transportation Intermediaries (OTI's) in the form of Freight Forwarders, Non-Vessel Operating Common Carriers (NVOCCs) and Third Party Logistics service providers. These companies are chain integrators: they organize the door-to-door chain, or part of it, including the maritime section of transportation and land transport. In this role, they function as direct customers of shipping lines as they typically book the shipments and organize the chain around them. When shipping lines move towards supply chain integration through door to door service they become competitors of their customers. OTIs are thus in the odd position of being positively and negatively impacted by poor alliance performance. On the one hand, OTIs are impacted by delayed vessel calls, poorly aligned chassis supply and changing carrier alliances in the same way as BCOs. On the other hand, OTI's sell themselves and make their money as supply chain experts who help their shipper customers navigate the complexities of international shipping. Who is best positioned to achieve (and want) a better supply chain integration: the representatives of the cargo-owners or the shipping lines? To put a cynical spin on it; what benefit would have standardized service metrics to enhance SCI provided either party? Would it not be better to keep actual performance measures somewhat vague? Given the increasing importance of these questions, how can alliances use standards for service differentiation and strategic planning?

This paper is organized as follows. In Section "Introduction" we introduce the context. Section "Conceptual Background" discusses development of cooperative arrangements in sea transport, airline alliances vs. ocean alliances, ocean carrier differentiation and supply chain integration (SCI) activity. Section "The Case for Standardization" discusses how standardization of services can be utilized. Section "A Conceptual Framework for Standardization through Terms of Service" introduces potential SCI standards that can serve as a model of service standardization. Section "Discussion and Conclusions" discusses the implications for management, policy, and further research. 


\section{Conceptual background}

\section{Cooperative arrangements}

Co-operative behavior has deep roots in ocean shipping. The concept of common carriage, where carriage must be offered, upon reasonable demand, to any who sought their services, was the impetus for agreements begun in the nineteenth century by ocean shipping companies to avoid destructive competition leading to company failures and irregularities in shipping schedules (Panayides and Wiedmer, 2011). In the twentieth century, Liner Shipping Conferences, composed of member carriers in different sea lanes, were utilized to stabilize rates, control capacity, and maintain adequate profit levels for the industry. The Conference system was much maligned but provided a measure of rate stability and a framework for carriers to effectively differentiate their service offerings (Clarke, 1997). Conferences did not directly prescribe service standards, though there was incentive pricing covering delay factors and ancillary services. The Conference system largely disappeared in major east-west trade lanes in the twenty-first century due to the advent of confidential service contracts and abolition of anti-trust exemptions.

Concurrently with the development of Liner Shipping Conferences, Vessel Sharing Agreements (VSAs) allowed ocean carriers to mutually cooperate through space sharing on larger vessels and provide schedule stability while reducing operational costs. Transport that would otherwise require each carrier to support a large fleet for all their sea-lanes on an individual basis could be rationalized to allow smaller lines in particular the ability to serve more destinations. This evolved into slot chartering agreements between two or more operators to ensure better economies of scale than container liner service performed individually (Cullinane and Khanna, 1999). VSAs typically were executed based on geographic coverage, port rotation, sailing frequency, the vessels in service, and participant's share in vessel spaces. A distinction between VSAs and liner conferences is that in a VSA each operator carries out its own marketing identity; its own bills of lading, carriage and handling including port terminals and land transport (Karmelic, 2010). VSAs enabled rates to be established to stabilize the trade and cover some operating costs such as ocean terminal arrangements (McLean and Biles, 2008).

Global carrier alliances began during the period of 1995/96 in both the global Transpacific and Asia/Europe networks (Damas, 1996). The growth of ocean carrier alliances has continued despite differing organizational objectives and level of mutual trust between carriers and intra-alliance competition. Alliances have gone by different names since their introduction to major trade lanes in the mid-1990s; these have included the Grand Alliance, New World Alliance, CHKY Alliance, and G6 among others. Rapid ongoing changes in Alliance membership have taken place within the last 2 years. At this writing, there are three major East-West shipping alliances that control the majority of container freight transportation between the U.S., Asia, and Europe.

\section{$2 M$}

Maersk Line A/S, Mediterranean Shipping Company S.A. (MSC), Hamburg Sud (acquired by Maersk), and a slot sharing agreement with Hyundai Merchant Marine (HMM). 


\section{Ocean alliance}

CMA-CGM S.A., APL (operating under CMA-CGM), China Ocean Shipping Company (COSCO) China Shipping (merged with COSCO), Orient Overseas Container Line (OOCL), acquired by $\mathrm{COSCO}$, and Evergreen Line.

\section{THE alliance}

Ocean Network Express (ONE)- a merger of NYK, K Line and MOL, Hapag-Lloyd Aktiengesellschaft (Hapag-Lloyd), United Arab Shipping Company (USAC) merged with Hapag-Lloyd, and Yang Ming Line.

Several mergers and acquisitions of major carriers occurred in the past year. Consolidation has been long predicted within the shipping trade press but had not actually taken place due to ownership issues, restrictions by national law, and cultural sensitivities (Jensen, 2015). Approximately 95\% of the cargo volumes moving in the major east-west trade lanes are currently aboard the carriers that are part of an alliance. The expectation is that merger and acquisition discussions will continue where potential cost saving synergies might be in place (Notteboom, 2015). Continuing merger talks may further alter the vessel sharing alliance structures and the vessel sharing agreements that underpin them. Scrutiny by international regulators intent on guarding against a single carrier controlling a major sea lane or one or two lines gaining excessive market share may make further consolidations difficult.

Global mergers and acquisitions taking place in the shipping industry can be thought of as a form of horizontal integration that adds economies of scale and increased market share to spur growth by offering similar or complementary services (Lee and Song, 2016). As business models change due to industry convergence they also provide a way to boost growth and innovation beyond the ocean carriage segment. The merger of CMA-GGM (CMA) with NOL/APL (APL) for example, created more control over port resources at particular locations for the ocean carriage segment. Both CMA and APL have terminal operating subsidiaries at this time (Terminal-Link owned by CMA and Eagle Marine Services owned by APL). The combined CMA/APL volume will provide the carrier with additional leverage to negotiate favorable rates and service with downstream supply chain partners that cannot currently happen in a carrier alliance. International regulating bodies will scrutinize the concentration of assets, and port communities may consider the adverse economic impact of having a port terminal controlled by one ocean carrier who could play a role in employment and economic decisions at the port (Lidinsky, 2015a). Port authorities using the landlord model of ownership have only a long term opportunity to renegotiate conditions affecting the port's economic viability (Holt, 2015).

\section{Airline alliances vs. ocean alliances}

Ocean carrier alliances are modeled somewhat on those created in the airline industry where each air carrier allows its partners to extend their market reach on a reciprocal basis. Airline alliances were driven by the need to reach a broader market while constrained by the limits of the airline regulatory framework. They were looked upon initially as marketing alliances to influence consumers' perceived value rather than a means of cost reduction (Wang, 2014a). The primary beneficiaries, however, were hub airports offering the best connections rather than the airlines themselves (Button et al. 1998; Lu, 2015). 
In economic terms, this was an example of perfect competition insuring the rents would go to the constrained factors of production. Similarly, the strategic alliances in liner shipping were attempts at cooperation between carriers on a global scale sailing to a handful of major maritime ports. Joining an alliance enables the carrier (air or ocean) to exploit economies of scale, enhancing their bargaining power with investments and purchases.

Maximizing accessibility at critical hubs is a critical factor in increasing market share and a major driver of competitive advantage (de la Torre, 1999). Air differs from ocean carriers in that only the transportation asset and arrival departure facilities need to be common, e.g., airplanes and airports). Air traffic must also follow a very controlled set of routes, altitudes, and landing patterns coordinated by the Federal Aviation Administration (FAA) in the US. Routes of aircraft and available airport gate space limit the supply of aircraft at major airports. Major airlines are subject to complementary asset requirements at a limited number of airports with adequate runway length, terminal capacity and associated investments in services, security, and even infrastructure for ground transportation. Airlines compete on frequency and timing as well as passenger amenities. For air freight, the competition will be around transit times, loading and unloading performance, and surface delivery vehicles to perform the ground portion of the services offered.

Container shipping, by comparison, requires significant complementary assets in the form of ports, chassis, trucks and trains to deliver goods to the beneficial cargo owner. Alliances sometimes require vessels to call on multiple terminals within a single port, making it take longer to unload cargo. Process innovation and implementation for enhanced SCI cooperation cannot be done without an adequate infrastructure or capabilities to support the vessel service. These specialized assets require a bilateral dependence between the ocean carrier and the owner of the complementary asset. For example, ocean carriers need to have marshalling yards (for stacks of containers awaiting pick-up) and terminal gate operations that are part of the port terminal. Warehouses for trans-loading in US, EU and other countries from ocean containers to domestic vans, and the return and marshalling of empty containers further add to the complexity. Up to $30 \%$ of an ocean vessel cargo can be empty containers.

Another difference between passenger air alliances and ocean carrier alliances is people versus things; for the air industry, the customer is the cargo; for ships, the $\mathrm{BCO}$, NVOCC or cargo user. For customers, air service starts with getting to the airport, and ends after discharge, baggage handling, and to some extent transport to destination. Ocean container service is much more heavily dependent on what happens after the cargo gets ashore. While the voyage itself may take the most time, shore side activities, including handling and travel to the cargo destination, present many more chances for delay, and a wide range of partners to coordinate. The increased chance for service failure reflects badly on the carriers, alliances and overseas transit intermediaries, as well as the onshore carriers and facilities. Greater integration of these onshore components, beyond the port and its environs, is needed to meet customer service for ocean carriage, as opposed to air carriage of passengers.

While there are distinct differences between airline alliances and ocean alliances, notably in the sheer scale of volume in a discharge of containers vs. passengers, ocean carriers can adopt some of the same benefits in terms of SCI. For example, airlines can 
influence customers' perception by enhancing brand equity and brand loyalty built around greater network access, seamless service, priority status, and enhanced conveniences on an expanded route network (Weber, 2005). The use of a common brand, a uniform service standard, and an identifiable asset can provide substantial integration of services as shown in successful airline alliances (Doganis, 2006).

\section{Ocean carrier differentiation}

The marketing effort undertaken by ocean carriers is on an individual firm basis and can differentiate between the parties to the alliance in terms of client relationship management from the moment the first encounter is made until final delivery of the cargoes to the destination (Panayides and Wiedmer, 2011). Similar to major air carriers, ocean carriers are limited in differentiation on the vessel asset. Airlines can offer enhanced services, (beds, meals, luggage delivery, etc.) to avoid being a commodity. Air carriers can command premium rates for premium service, though larger customers can demand the premium service at a rate they dictate predicated on volume. Ocean carriers can differentiate on elements important to beneficial cargo owners (BCO's). For example, documentation for cargo movements is of critical importance and must be managed by BCO's. Ocean carrier information, including where the cargo is in transit and when it will arrive at the next milestone, invoicing, global account coverage, etc. are aspects that can be controlled by the carrier and provided to BCO's (Landon, 2015). The growing power of NVOCCs within trade lanes is due to their ability to more adequately provide the visibility into their ocean-borne cargo and other "soft services" that are important to the $\mathrm{BCO}$ without the expense of operating the equipment assets; they can leverage the available capacity to their advantage. Control of key service trade lanes where ocean carriers have a disproportionate amount of vessel slots can also allow them to market themselves as having full control of the service.

\section{Liner shipping requirements, vessel sharing agreements and OTI's}

The ocean shipping alliances have had an effect on tightly integrated sailing schedules. Given that container liner shipping has to plan schedules months in advance, high demands are placed on smoothly running port procedures and ships. Any deviation from a schedule plan can cause problems- particularly now that shippers have integrated container transportation chains in their planning procedures and logistics processes. For shipping services to run smoothly it makes sense to run a uniform, homogenous fleet of container ships, with similar container stowage capacity, speed and reliability. The existence of large vessel sharing agreements adds an additional level of complexity; freight rates are offered by each operator on an individual basis for the carriage of cargo booked by them. Partners in alliances with vessel sharing agreements have competitive positions where each of them carries out its own marketing, issues its own bills of lading, performs the carriage in its own or hired containers, and handles its own customer cargo as well as customer or liability claims (Karmelic, 2010). These operational issues become important when procedures must be put into place to handle negotiations with land transport operators where synergies are attempted based on volumes achieved by partners. An increase in ship or port size does not result in profitability unless the asset's full capacity is utilized at a feasible tariff or freight rate for interconnectivity. 
There are some operational port activities alliance carriers now do in concert to reduce overall operating costs and increase asset utilization. They include Joint Terminal Procurement where negotiations with port operators can be done to reduce costs for storage, security, container handling, refrigerated (reefer) container handling and the like (Glave et al., 2014). Block container stowage onboard for large volume customers and terminal based appointment systems have been put in place to maximize efficiency of terminal resources (Davies \& Kieran, 2015). Joint rail vendor procurement and joint motor carrier procurement have also been put in place to better coordinate vessel arrival and cargo availability (Davies \& Kieran, 2015).

As previously mentioned, ocean carriers are far more dependent now upon space allocations for NVOCCs, Global Forwarders and Third Party Logistics Operators. The larger non-asset service providers can get better prices from the steamship lines which they can resell to the Beneficial Cargo Owners. This offers BCOs greater flexibility to move cargo on various ships rather than those within their slot-sharing agreements. These ocean transportation intermediaries represent substantial cargo share to a Vessel Operating Common Carrier (VOCC) but are a more volatile segment of the market and rely on adding value to earn their fee in marked-up pricing. The alternative is to generate their income from commanding a volume discount from the VOCC and charging $\mathrm{BCO}$ market rates. In either case the result to the VOCC is a large customer with a price sensitive commodity and less brand loyalty than a $\mathrm{BCO}$ may have.

\section{Supply chain improvement efforts}

As alliances have grown and changed there is much concern over the effects they may have on competitive policies for the shipping public and the buying power that large container lines and alliances have over ports, cargo terminals and other services (Merk, 2016). Alliances have come under severe criticism from shippers for poor quality of service, disruptions to supply chains through the bunching of vessels, voided sailings, and other delays (Global Shippers Forum, 2015) though no research studies to date substantiate this claim. One option to alleviate pressure on ports is supply chain integration ( $\mathrm{SCI}$ ) beyond the quay, using complementary services (Franc and Van der Horst, 2010). Supply chain integration can be defined as "a process of redefining and connecting entities through coordinating or sharing information and resources". It creates linkages between partners who have different interests in the same supply chains, and/or who have similar interests but participate in multiple supply chains. For example, a terminal operator could share information about schedules with other terminal operators, carriers, shippers or port authority to better schedule the movement of containers in and out of the ports. Efforts at enhancing SCI between ocean carriers and their stakeholders have been researched by Lam and Voorde (2011); Tseng and Liao, (2015) among others. Some progress has been made using information such as load profiles at seaports to assist terminal operators in devising unloading schedules and yard management. Efforts to look for cooperative complementary integration further downstream in the supply chain are rare, though they do occur (Song and Panayides, 2002; Van der Horst and Van der Lugt, 2014). Tighter integration with prominent supply chains could provide a source of value added for ocean carriers if they are seen as the prime movers of the efforts. Coordinated efforts to improve integration downstream toward the destination by ocean 
shippers, mediated by standardization, will result in better differentiation for individual carriers regarding logistics costs, better performance and service, and more business on specific routes for alliances (Bagby, 2015; Notteboom and Rodrigue, 2005).

Shipping customers are interested in the entire supply chain service performance, and may have different service requirements even within the same supply chain. For instance, one component for a manufacturer could be needed on a Kanban or just-in-time basis with little inventory, so that delays are not tolerated well; whereas another component may be easily and inexpensively stockpiled and may be purchased to obtain quantity discounts, with delivery speed and timing not an issue. Currently these service levels must be handled within individual contracts created throughout the supply chain, and there is no mechanism or standard the carriers could use to consolidate and coordinate handling and movement procedures to obtain the specific desired performance. It is entirely an incentive based system of coordination (Aoki, 2007; Van der Horst and Van der Lugt, 2009), and since the coordination is at the individual contract level, it is fractionated even within one supply chain. Supply chain carriers cannot see how to aggregate classes of service of different supply chains to improve chances of satisfying the service criteria expected.

Changing business models in response to the introduction of SCI arrangements within alliances may eventually stabilize the international shipping market, leading to better differentiation for individual carriers regarding rates, performance, service and increased business on specific routes. Rates offered to cargo proffered by BCOs and NVOs should cover costs as well as provide a reasonable rate of return to encourage investment, especially in downstream (inland) service providers such as multi-modal transport operators. The fact that NVOs and other third parties are proxies for cargo owners reminds us that they must make profits as well, and therefore will recommend bookings that make them money, not necessarily bookings that are truly in their customers' best interest. The business has converted from a two-echelon to a three-echelon model, and the BCOs and ocean carriers now have the problem of controlling a supplier's supplier. The recent history of multi-echelon supply chains shows clearly how difficult this control can be. Disruptions at lower levels of supply ripple through the chain, but it is not enough for the cargo owner to have service level agreements with the first level of supply. They must insist that supplier's suppliers satisfy standards of performance as well. This is not an easy task, and effectiveness is highly dependent on the financial leverage they have over any of these partners. In short, small BCOs have little influence; large ones can have considerable influence, but their influence on the alliances will be second or third hand.

\section{The case for standardization}

Standard setting can enhance cooperation when complementary products or services are part of the offer (Bagby, 2015; Leiponen, 2008). In industries such as electronics and computing, complementary products and services have become paramount in marketing any product.

Given the complexity of international trade rules and regulations, the idea of standardization outcomes in ocean transportation is a contentious issue for practitioners. Cooperative organizations exist in all industries and can include industry associations, consortia, alliances, and formal standards-development organizations (Rosenkopf and 
Tushman, 1998). The International Chamber of Commerce International Commercial Terms (INCOTERMS) that spell out buyer and seller transport payment terms and the United Nations Convention on Contracts for the Sale of Goods (CISG) contracts are examples that directly affect shipping. Carriers that participate in shipper alliances have a greater impact on the formation of potential supply chain standards. Within the shipping industry, one can view the advent of $20^{\prime}$ and $40^{\prime}$ containers adopted by much of the shipping industry in the mid to late 1960's as a standard that generated a host of complementary traffic for carriers of all kinds. Container variety prior to standardization retarded competitive product and service diffusion desired by customers (Bagby, 2015).

In supply chain sustainability we have seen some progress on such issues as treatment of employees by subcontractors, health rules, and quality through standards application. Frequently the standards have been written by international agencies or nations. When a supplier is in one of these nations, the procurer simply needs to insist that the supplier is in compliance with the applicable standard. Not only does the contractual language become clearer, but monitoring may then occur in conjunction with that of NGOs, governments, or world agencies, helping to reduce its transaction cost. Similar benefits could occur from having external performance standards agreed to by all. However, ocean shipping is not governed by any uniform law; the closest we come is with the IMO and SOLAS rules. These do not pertain to performance in a supply chain context. Clearly there could be a benefit from standards of performance.

If disconnect exists between the cargo shipper's view of the supply chain and the ocean carrier's view, then there is no coordination on a performance measure. This is a gap between customer and manager perception. To close it we need a common understanding of the measures to establish quality of the service. This is where service standards need to be set. The relationship of service between cargo owner and carrier is not present in the INCOTERMS that connect buyer and seller through the contract. They define where responsibility lies for various relevant expenses, paperwork, custody, and liability. They are embedded in a legal agreement over the items covered, but do not say who is responsible for late product, except in a very general way. (INCOTERMS are reviewed and updated each decade.)

At present the movement of full container loads is defined in specific Port/Ramp or Door terms. These outline the responsibility of the carrier under the terms of the Ocean Bill of Lading. A move towards standardization suggests the need of terms that define levels of service and where and how they are measured, across all participants in transport chains, similar to INCOTERMS. If these were standardized, then ocean carriers would be certain of the requirements for service from the downstream agencies. Levels could be stipulated and charged for, or assigned to different supply chain elements, as are different INCOTERMS levels. Cargos could be placed by service level to promote improved speed at each interchange.

Information related to the location and position of the ship is normally available via the track and trace component of each individual carrier's website. Information could be expanded to include many aspects of loading/unloading at the terminal. However, many merchants with shipments under Door terms as spelled out in INCOTERMS allocate responsibility for defining warehouse delivery between the contracted motor carrier and the warehouse itself. All motor carriers for example can call prior to delivery to avoid waiting time. But warehouses are not always accommodating to the 
needs of a motor carrier for prompt loading and unloading. This is currently a problem in the U.S. trucking segment where a truck picks up a container from the port only to find the destination warehouse is closed for business. The result is delay for the $\mathrm{BCO}$, but also the cost of down time for the trucker.

Within the U.S. port terminal, the terms of the Uniform Intermodal Interchange Agreement (UIIA) require that the equipment provider make known equipment return locations prior to $1600 \mathrm{~h}$. Otherwise, the motor carrier will return the equipment to the location where it was originally interchanged. Some equipment providers do this on their own websites or through group efforts such as www.returnlocation.com. The UIIA is in the process of building a matrix for all equipment providers on their own website. Recently, however, supply chain partners have been unilaterally changing standard terms for their own benefit, disrupting the carrier plans. We suggest that the carrier alliances could have a greater role in equipment returns within ports as part of a Service Agreement.

In Section "A Conceptual Framework for Standardization through Terms of Service", we will present a possible system for service attainment measures that could be managed through cooperative standard setting. We also give estimates of the range of improvement possible in these measures through specifications provided by alliance networks.

\section{A conceptual framework for standardization through terms of service}

\section{Current and proposed models}

Basic marketing suggests that customization and flexibility is given up when focusing on cost alone. There is a segment of shippers willing to pay for additional services such as faster transit times. But the proportion willing to pay such a premium is not sufficient to actually fill the vessels or reorder port rotations (Landon, 2015). Canceled voyages or services often occur and may escalate (Leach, 2015).

Carriers deal with many different supply chains; the integration problem is highly complex. With a morass of individually negotiated arrangements for performance, there is no common basis for choosing consolidated flows such as onshore berth or yard performance, or rail transport via unit train. Carriers engaged in vessel sharing alliances can endeavor to select common marine terminal operators (MTOs) so that their vessels work efficiently and are not made to call multiple facilities in the same port location. This avoids shifting costs and time, and additional labor orders and guarantee periods. Some VSAs are filed with the FMC to allow for joint negotiation in the MTO procurement process, so that each carrier is able to achieve common terminal costs on the basis of the entire volume represented by the consortia. While some carriers select common landside service providers, this is complicated due to long term contractual obligations.

We present an example of an adjustment below from Asian ports to West Coast US. The current operational cycle has the load MTO sorting export cargo by port of discharge (POD), size/type and weight as this is the most efficient layout for yard and stevedoring efficiency as shown in Fig. 1a.

In (a) the import cargo is received by the discharge MTO and sorted into an import 'super stack' for local truck delivery as well, or on and off-dock rail interchange and special sorts (A and B) for large volume motor carriers and BCO's. The special sort represents an improvement on previous import stack arrangements, and allows a single motor carrier to receive the next available container in the stack. Additional efficiencies 


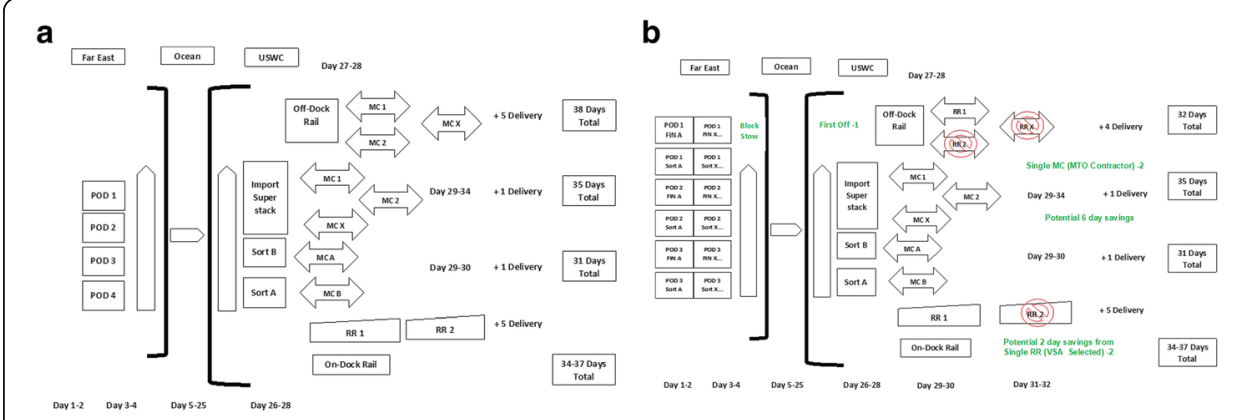

Fig. 1 Current (a) and Potential (b) Carrier Alliance Flow Schematics (source: author drawing, from discussion with liner executives)

may also be possible by MTOs moving to a drayage appointment system but this may be complicated by the existing warehouse appointment structure already prevalent in much of the U.S. supply chain.

The rail segment offers the best opportunity for vessel sharing agreement (VSA) collaboration. Both on and off dock rail operations suffer from inefficiencies born of the need to effectively share limited terminal resources, in terms of yard equipment and yard and track space. For on- terminal rail operations, improvement can be achieved, as shown in Fig. 1b, by each VSA selecting a single rail carrier so that the on-terminal track capacity can be allocated to coincide with a particular vessel's discharge operations. By doing so, no cargo will be delayed waiting for a second rail carrier's train to arrive on the facility to find that it is only blocked by the first rail carrier's train. Off terminal, the issue is further complicated by the competitive environment in port drayage and the scale of these carriers, who are potentially unable to provide the number of tractors required to move a large amount of cargo in a limited amount of time. This issue cannot be immediately solved by the VSA selecting multiple motor carriers as it will be difficult to align the purchase order and payment process. The MTO may contract this work on the VSA's behalf, if only to provide a common billing platform between alliance partners and marine terminal service providers.

A conundrum in the supply chain is that efficiencies at the import marine terminal are typically solved by additional efforts exhibited by the export marine terminal. If all facilities were balanced between imports and exports, this issue would be easy to reconcile. As this is not the case, MTO's will need to develop coordinated procedures to ensure the success of the supply chains they are serving. Another complication arises because so much of the cargo is booked by OTIs. They may have their own choices of ports, MTOs, and downstream carriers, which might conflict with those preferred by the ocean carriers.

A lesson from the examples in Fig. 1a and b is that the heart of the complexity of service level agreements is far beyond the simple configuration of arrivals at the port. Both figures show the overlap of supply chains beyond the port. Furthermore, not only do multiple supply chains use these resources, but individual chains overlap, and even in the same chain have different requirements for different cargoes. While integration with the port terminal itself is a start, there are potentially many uncoordinated factors. The risk of delay or error goes up with the number of partners and the overlap of individual customer supply chains implies that factors along the way may have an agency conflict that might create preferred treatment for one or the other chain on quixotic grounds. A standard Terms of Service which applies 
to the whole chain would assist these intermediate partners downstream to determine how to coordinate with each other through an aggregated classification of cargos.

\section{Proposed service terms standard}

INCOTERMS designations have provided a standard coordination mechanism for contracts. We suggest standardizing service coordination in a similar fashion. Use of the standard will allow cargoes to be aggregated according to the level of service required, regardless of the specific contract for each container. However, as with INCOTERMS, individual contracts can modify terms as they wish. Standardization, if successful, will induce conformity as it has with INCOTERMS; carriers can plan and coordinate activities to attain the prescribed service levels without looking at each contract as an exception.

ServiceTerms is a six-star $\left(6^{*}\right)$ system. A star means the defined star level of service performance is reached in one of six categories of service. The categories follow the acronym ACTION; category definitions and proposed standards appear in Table 1

Table 1 Service Terms ACTION categories with prototype standards and metrics

\begin{tabular}{|c|c|c|c|c|}
\hline ID & Name & Services included & Star standard & Metrics \\
\hline A & Accessorial & $\begin{array}{l}\text { Accessorial or extra services requested } \\
\text { or required by the service. Examples: } \\
\text { Humping, handling charges, labeling, } \\
\text { packing, etc. }\end{array}$ & $\begin{array}{l}\text { Service adds less than } 1 \% \\
\text { of quoted delivery time to } \\
\text { the actual delivery time }\end{array}$ & $\begin{array}{l}\text { Performance time of } \\
\text { service on the cargo. }\end{array}$ \\
\hline C & $\begin{array}{l}\text { Customer } \\
\text { service }\end{array}$ & $\begin{array}{l}\text { Factors required by the service related to } \\
\text { quality of the service; in this category fall } \\
\text { any service factors that can be measured } \\
\text { by remote sensing or devices, as } \\
\text { opposed to data entry in IT systems. } \\
\text { Examples: Load tracking requirements, } \\
\text { quality maintenance, safety, damage } \\
\text { tracking, temperature, moisture } \\
\text { exposure, motion, sensing or } \\
\text { measurement. Also included is the } \\
\text { estimated delivery time provided } 24 \mathrm{~h} \\
\text { prior to trip start, since the actual can } \\
\text { be tracked real time. }\end{array}$ & $\begin{array}{l}\text { Service adds less than } 1 \% \\
\text { of quoted delivery time to } \\
\text { the actual delivery time }\end{array}$ & Actual vs quoted time. \\
\hline $\mathrm{T}$ & Transport & $\begin{array}{l}\text { Factors relating to actual movement of } \\
\text { the goods in conveyances, or during } \\
\text { the time they are being moved or } \\
\text { supposed to be. } \\
\text { Equipment availability: chassis, railcars, } \\
\text { cranes, loaders, berths, time limits. Unit } \\
\text { train or bundled service requirements. }\end{array}$ & $\begin{array}{l}\text { Follow laws of country, } \\
\text { jurisdiction, or flag. } \\
\text { Speed standards (km/h). } \\
\text { Adds less than } 2 \% \text { of } \\
\text { quoted delivery time to the } \\
\text { actual delivery time }\end{array}$ & $\begin{array}{l}\text { Actual vs standard } \\
\text { movement speed. } \\
\text { Delay times. }\end{array}$ \\
\hline I & Inventory & $\begin{array}{l}\text { Factors of stowage, demurrage, } \\
\text { warehouse time, goods in static } \\
\text { locations. Handling, in-and-out, } \\
\text { trans-loading, crossdocking. }\end{array}$ & $\begin{array}{l}\text { Service adds less than } 1 \% \\
\text { of quoted delivery time to } \\
\text { the actual delivery time }\end{array}$ & $\begin{array}{l}\text { Actual vs standard } \\
\text { times. }\end{array}$ \\
\hline $\mathrm{O}$ & $\begin{array}{l}\text { Orders and } \\
\text { papers }\end{array}$ & $\begin{array}{l}\text { Commercial documents, invoicing, } \\
\text { collection, payment for any services or } \\
\text { material, customs papers, insurance, doc } \\
\text { preparation and communication to } \\
\text { proper parties. } \\
\text { Activities which might reasonably be } \\
\text { handled by information technology are } \\
\text { included here whether or not it is } \\
\text { actually handled by IT or manually. }\end{array}$ & $\begin{array}{l}\text { Adds less than } 2 \% \text { of } \\
\text { quoted delivery time to the } \\
\text { actual delivery time }\end{array}$ & $\begin{array}{l}\text { Actual vs standard } \\
\text { times. }\end{array}$ \\
\hline $\mathrm{N}$ & $\begin{array}{l}\text { None of } \\
\text { above }\end{array}$ & $\begin{array}{l}\text { Factors relating to anything not } \\
\text { covered in the five categories above. } \\
\text { Used when a contract has requirements } \\
\text { for service performance that must be } \\
\text { specifically stated in the contract. }\end{array}$ & $\begin{array}{l}\text { Factor agreed standards in } \\
\text { contract met. } \\
1 \% \text { and } 2 \% \text { rules can be } \\
\text { quoted. }\end{array}$ & $\begin{array}{l}\text { Measures defined in } \\
\text { contract. } 1 \% \text { and } 2 \% \\
\text { rules can be referred to. }\end{array}$ \\
\hline
\end{tabular}


below, which includes a definition of what service components belong in each category, what the performance standards for that component in the category are, and how they might be measured. The CTIO categories are those from the survey in Lam and Voorde (2011). A is for accessorial services, such as hazardous material or phyto-inspection, not covered in other terms; and $\mathrm{N}$ is for requirements not otherwise covered. The particular contractual ServiceTerms will be applied from the start of handling in the Origin city to the end of handling in the Destination city, thus defining fairly precisely the scope of the supply chain service agreement.

ServiceTerms in an agreement are listed as follows: ServiceTerms designator, Origin, Destination. The ServiceTerms designator must cover all 6 of the ACTION categories, and may be written as a six-character field. If parties to a ServiceTerms agreement cannot meet the star standard for a component, it is listed as an exception for its category in the ServiceTerms designator. If several of the categories are accepted at the star level, then those stars may be abbreviated with a numeric indicator for the number of stars. Any exception categories will be denoted by the appropriate category letter. Thus 3*AIO or ****AIO would represent exceptions for accessorial inventory and orders, and star level service standards for customer service, transport, and all others ( $\mathrm{C}, \mathrm{T}$, and $\mathrm{N}$ respectively).

If a cargo has a ServiceTerms designation, all agents in its supply chain will be aware of the requirements. They will be able to determine if they can comply with the terms, or they need to negotiate special contractual terms that would possibly change the $6^{*}$ designation. When planning how to handle this cargo they would be able to group it with others requiring the same handling, much as LTL truckers consolidate packages with similar delivery traits. This would allow each agent to develop her own plan for efficiency for this cargo.

In performance measurement we suggest two rules we call the Delay (1\%) and the Move (2\%) rule. Clearly the percentages could be negotiated during standard setting; ours are first estimates. To establish performance using these rules, the estimated time for the entire trip must be available at the start of the trip, and the partners' systems must track and report the delay times or start and end times to all partners as they occur so each variation can be calculated by all parties when cargo arrives. Collecting this information will be enabled more and more by the increasing use of so called Internet of Things data collection and real-time monitoring systems. Automated facilities have the suitable data routinely available, but the standard does not require automation; electronic records from work sheets or EDI could be used by partners who do not automate the data gathering.

The Delay or $1 \%$ rule is used for times spent in components of activity when the cargo is not moving a long distance; for instance, in a warehouse, yard, or terminal, where one expects the activity to be completed in a relatively short period. These types tend to have a scope that is in one facility, and are less likely to be affected by exogenous issues. In the Delay rule, agent activity may not add more than $1 \%$ of the total estimated movement time for the whole chain delivery. Anything exceeding that will not meet the * standard.

The Move or $2 \%$ rule is used for movement times. It states that a component move activity must not add more than $2 \%$ of the total estimated movement time through issues in the movement, such as slow steaming, crew exchanges, safety stoppages, bottlenecks, equipment shortages, etc. These moves have a greater chance of 
exogenous causes of delay, such as weather or wait for berth or tide. If that standard for the whole trip is exceeded the component activity does not meet the * standard for its category.

\section{Use of the service-terms model}

As an example, consider a cargo the alliance carries destined for Customer 1 using the Current and Potential alliance scenarios of Figs. 3 and 4 respectively. This customer utilizes the off-dock rail and motor carrier facilities depicted in the First-Off option at the top of the Potential example.

The total trip time is $38 \mathrm{~d}$ or $33 \mathrm{~d}$. What the customer expects would include the variation added in the * standard and no more. The 1\% Delay times and 2\% Move times are indicated. If this cargo were shipped under $6^{*}$ service, total delay could not exceed the amount in the * variation line over all without the delivery violating the $6^{*}$ agreement. Further, by tracing the in and out times at each node, partners could see what was contributing to the violation; customers might or might not be told who was responsible. This would provide enough monitoring to allow members to examine in some detail which ones are meeting commitments to the "standard, and which are not.

Note that in long chains with more partners and more connections such as depicted in Table 2, the delays could accumulate. A shipment could still meet $6^{*}$ standards if each factor were just a bit under its limit. Thus for this agreement, the maximum durations would be $42.5 \mathrm{~d}$ or $36.9 \mathrm{~d}$ respectively. This is actually $11.8 \%$ longer than the estimated commitment of $38 \mathrm{~d}$ or $33 \mathrm{~d}$ under the $6^{*}$ Service Terms. So the customer knows the projected variability in the delivery time. In addition, downstream agents could make up lost time in upstream stages to right the course of early delays and meet the customer's expectation.

Figure 2 shows quantiles from our example using the implied standard deviation, setting limit times as the standard, one standard deviation, and max delay percentile of the underlying normal distribution of the standard trip (vertical lines). The normal distribution is appropriate because the trip is a sum of times taken by the different agents, via the central limit theorem.

Table 2 Example of Service Terms standard applied to Figs. 2 and 3 (Source, author)

\begin{tabular}{|c|c|c|c|c|c|c|c|}
\hline Current example & $\begin{array}{l}\text { Stage } \\
\text { time (d) }\end{array}$ & $\begin{array}{l}\text { Delay } \\
(1 \%)(h)\end{array}$ & $\begin{array}{l}\text { Move } \\
(2 \%)(h)\end{array}$ & $\begin{array}{l}\text { Potential alliance } \\
\text { example }\end{array}$ & $\begin{array}{l}\text { Stage } \\
\text { time (d) }\end{array}$ & $\begin{array}{l}\text { Delay } \\
(1 \%)(h)\end{array}$ & $\begin{array}{l}\text { Move } \\
(2 \%)(h)\end{array}$ \\
\hline Pod & 2 & 9.12 & & Pod/Sort/Fin & 2 & 7.92 & \\
\hline Stow & 2 & 9.12 & & Block Stow & 2 & 7.92 & \\
\hline Voyage & 21 & & 18.24 & Voyage & 21 & & 15.84 \\
\hline Yard Stack/Sort & 3 & 9.12 & & Yard Stack/Sort & 1 & 7.92 & \\
\hline Off-Dock Rail & 2 & & 18.24 & Off-Dock Rail & 1 & & 15.84 \\
\hline$M C$ & 3 & & 18.24 & $M C$ & 1 & & 15.84 \\
\hline Warehouse & 2 & 9.12 & & Warehouse & 2 & 7.92 & \\
\hline Delivery & 3 & & 18.24 & Delivery & 3 & & 15.84 \\
\hline Total Time & 38 & 36.48 & 72.96 & Total Time & 33 & 31.68 & 63.36 \\
\hline *Standard variation & $4.56 d$ & & & *Standard variation & $3.96 d$ & & \\
\hline $\begin{array}{l}\text { Worst case } \\
\text { meeting *standard }\end{array}$ & $42.5 d$ & & & $\begin{array}{l}\text { Worst case } \\
\text { meeting }{ }^{*} \text { standard }\end{array}$ & $36.9 d$ & & \\
\hline
\end{tabular}




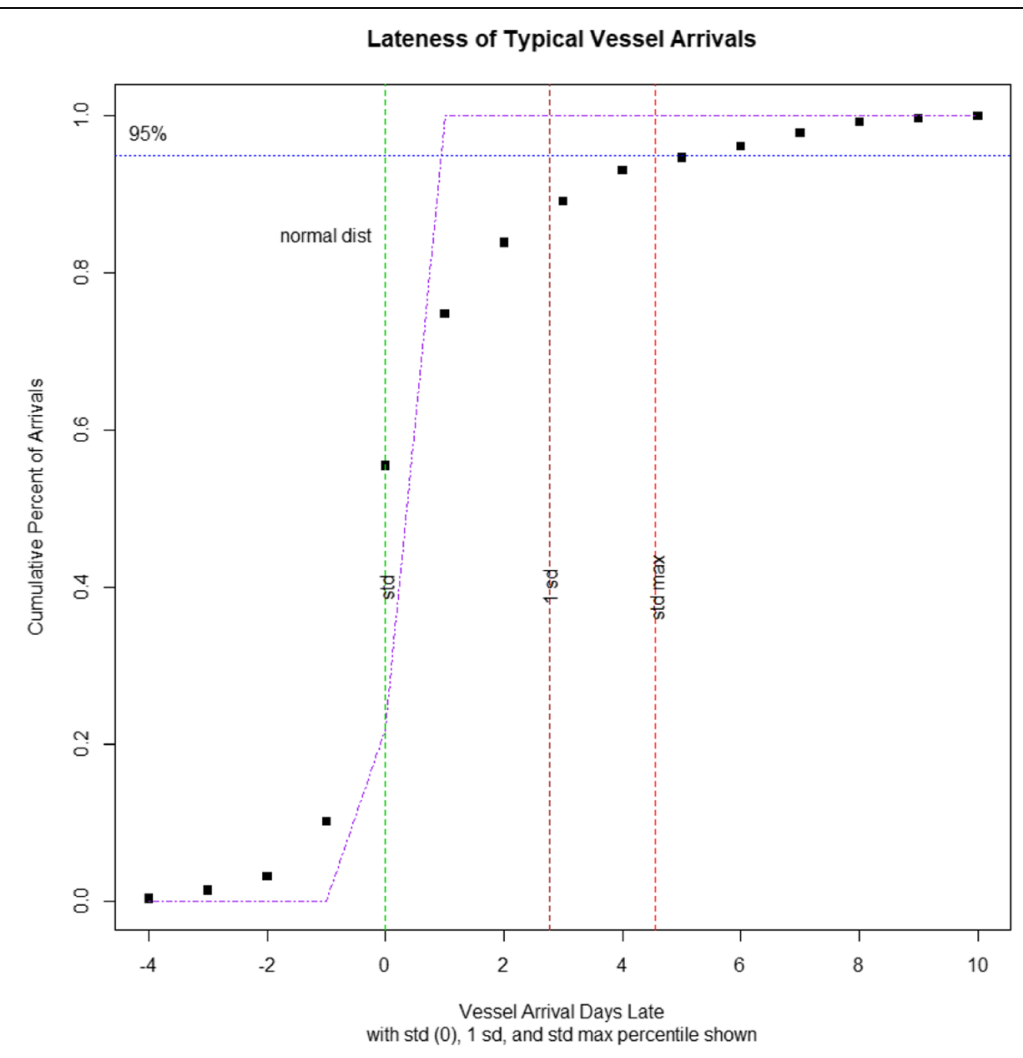

Fig. 2 Lateness quantiles implied by 6-Star example and data from Harrison (2013) for liner vessel days late. Parameters selected for example are in line with the exogenous example and appear consistent with normally distributed lateness. Left of the red vertical line represents the $6^{*}$ standard allowed lateness. Source: author graph from Harrison (2013) sample data

The points in Fig. 2 represent data from a typical Drewry's study of days late for a maritime ship service, the longest transit time for any agent in the supply chain. A normal with mean 0.06 and standard deviation 0.086 has a $95 \%$ quantile at 0.208 days. The Drewry's data exhibit more long late delays and more slightly early arrivals than the normal distribution. The 95th percentile of the real data is about 5 days, greater than the 4.56 days of the maximum $6^{*}$ limit. Many maritime voyages do occur on time, but the delay for missing a scheduled service might occasionally inject a weeklong delay waiting for the next voyage. Its time distribution might be bimodal. However, evidence is that week skips are not common (Harrison, 2013; Notteboom, 2006). The analysis therefore shows that the $1 \%$ and $2 \%$ overages may be consistent with actual maritime data, taking into account ocean shipping in general has a relatively low on time arrival percentage, which customers expect to be improved.

We might expect from the literature that the bulk of the delay issues would occur in the shoreside part of the trip. That is reasonable because of the many agents involved in the latter shoreside part. Fig. 3 shows that the primary sources of schedule unreliability on voyages are onshore at the port or terminal. These account for over $85 \%$ of the delays in the study by Notteboom (2006). The next three, totaling about $13 \%$, are voyage related. Missing a convoy was responsible for less than $1 \%$. Reducing bad 


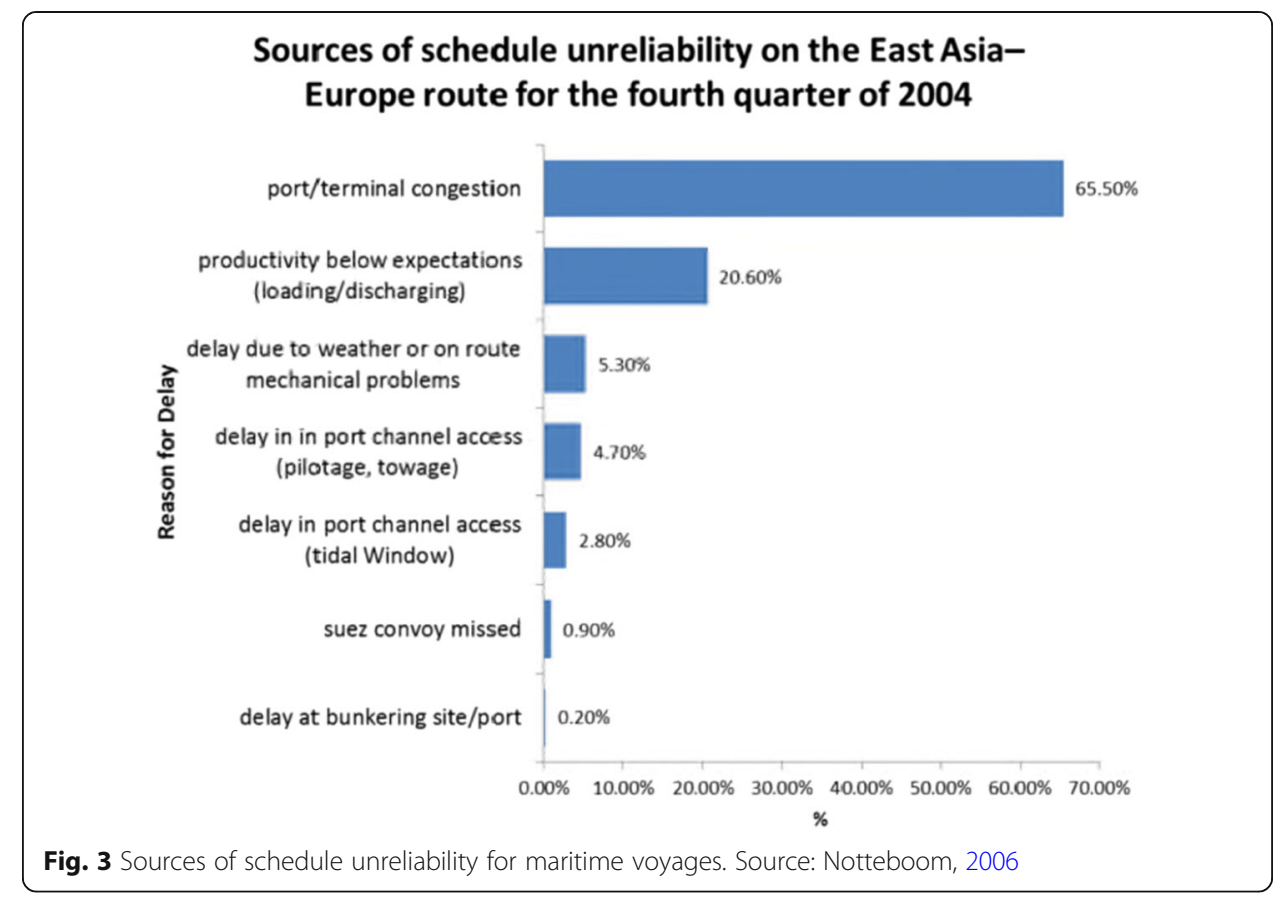

variability of D2D movements means attending to delays on the onshore part (Harrison, 2013). But most of these have relatively short handling periods; they are given more latitude proportionately by the $1 \%$ or $2 \%$ of total trip time rule; though the voyage length contributes much more to the variation, the standard deviation goes up as the square root of the number of days.

Research dealing with distributions of supply chain lateness is not plentiful, though there is more interest recently. Clark et al. (2014) pointed out that supply chain uncertainty translates directly into safety stock and raises inventory cost. The result is a barrier to trade, since this results in a 'tariff' of 2 to $27 \%$ of product value. Leachman (2008), drawing on his extensive experience with the US West Coast San Pedro Bay ports (Los Angeles and Long Beach), documents in terms of inventory cost the nature and effect of delays at these ports just after landing.

Fransoo and Lee (2013) summarized some of the issues concerning supply chain delays, suggesting strategies including capacity investment for port authorities, optimal ordering policies for shippers in the light of dynamic shifting of maritime chains, the value of information sharing, and pricing. They point out that current operations are aimed at optimization of expensive resources at sea and port, rather than hinterland transfer and transport. They suggest improvement can occur only as overcapacity builds at terminals, leading to ocean carrier control of supply chains, and ultimately to carrier competition on serving end customers.

This is not our view. We believe focusing on the operational improvements through evaluation and coordination of all the agents, meeting end customers' needs, is a viable approach. Standardizing the service terms for all agents in the chain is an important step, so that each can develop her own approach to meeting the goals set, rather than relying on a coordination driven by market power. Just as Amazon did for e-commerce through two-day shipping, chain-wide standards of service performance could motivate better cooperation and coordination of all agents. 
If Overseas Transportation Intermediaries chose, they could take responsibility for the delays on all the links they are managing, and provide a coordination point to reduce the variation. They would have an advantage doing so because in exchange for agreeing to manage the passage time they would be able to take advantage of the potential randomness of the delays. If the probability of a particular link having an excessive delay is small, it is likely that most parts of the passage they control could be completed in lower times, and they would be able to suffer a larger delay at one node without missing the 6 * Service-Terms standard overall. Thus the standard serves to aid coordination to reduce delay.

Using Service-Terms would allow the coordinated handling of all the $6^{*}$ shipments using similar performance standards, cargo placement, yard routing and scheduling, and so on. Fewer categories of aggregation mean better predictions and better performance of the load plans at both ends of the voyage link. This is depicted in the Potential system of Fig. 1b. The vessel operators would optimize relative to the aggregate categories rather than around individual customer specifications within their stowage plans. For example, consider the Yard Stack/Sort stage in Table 2. By grouping the $6^{*}$ shipments, similar handling would ensure similar performance times.

What the diagrams do not depict is customers whose supply chain is more complex. For instance, a manufacturer may source many supplies from Asia and use all 5 pictured paths for different shipments, depending on her forecast, inventory, and safety stock timing and requirements. Specifying $6^{*}$ Service-Terms for every supply chain shipment would simplify the process of coordinating standards of performance in all the chains, and provide a definitive estimate of variability. The shipper might prefer this to outsourcing their entire supply process to a Third Party Logistics provider; it would coordinate the service level of the deliveries without the necessity of a single contract, or the agency issues attendant on hiring a 3PL.

\section{Pros and cons}

This standard provides a uniform set of performance measures that all partners can apply to their own portions of the supply chain movements. It allows operators serving many supply chains to aggregate handling by the category of service required. Thus six-star shipments would be handled so as to receive the highest grade of service response by each partner. Each partner would be able to determine how to meet the standard; which performance improvements to enact. Should the partner fail to meet the standard too often, they will be penalized by other partners not including their services in the future. Since each performance failure will be tracked along with the individual participants' contributions, it will be easier for shippers to determine which chain mechanisms are delivering the grade of service they seek.

For many alliances, the ocean carriage part takes most of the time, and therefore the inventory (which hits the books of the owner) is doing nothing; but it cannot be avoided. The inland transit pieces in the model have a much shorter time, at least in perception, to do their work and move the merchandise on, and there are many partners. Efficient management by these partners and their agreements is therefore the only way to make up time. In addition, these inland transit pieces compose more of the 
cost than the ocean voyage. Coordination of the service requirements should also allow cost reductions through efficient management.

Disorganized onboard container storage from multiple alliance ships is often mentioned as a primary impediment to port efficiency at the port of discharge. However, this is often created by efforts at the port of loading to avoid multiple "sorts" of cargo requiring dedicated terminal yard equipment that complicate their own handling efficiencies. A stow plan has to address operational constraints at both the loading and unloading points. So it is not clear that optimizing for the unloading terminal is optimal for the entire supply chain. It should not be seen as a solution for the service quality standards dilemma.

One downside of a standard is that definitions for the ACTION items must be agreed on by several major parties to achieve critical mass. This could involve considerable time and effort on the part of partners. A standards group has to lead; INCOterms were created by a similar process. It is possible that competing standards could arise, engineered by NVOOCs, 3PLs and major freight forwarders, or other groups. Competing standards would not improve the process as much as a unified standard would; eventually commonalities would develop.

Additional data and targeted performance metrics may reveal specific areas where ports, regulating bodies, trucking interests and alliances can work together to implement new approaches to alleviate the root causes of port congestion and enable freight transporters to cost effectively keep up with demand. These metrics could be incorporated into the ServiceTerms standard via periodic revisions.

Once the standard is in place, how should any penalties for lateness be allocated? Similar to INCOTERMS, no economic incentive for compliance is present. Individual contracts could cover this piecemeal as with INCOTERMS; however, compliance incentives or enforcement could strengthen the structure.

We feel that since the supply chains are a cooperative enterprise, benefits or costs of should be shared by all partners. The logic is that each agent should try her best to reduce delays on her part to allow safety-stock time for potential later disruptions. The $6^{*}$ system allows some slack for compliance. If the early acting agents are all just within the standard for their segment, this leaves little slack to make up for unexpected delays later on. Just as in project management, building in a little slack time may allow the entire chain to deliver a higher percentage of successful service. A late trip should therefore be a shared burden to the agents; all could have done something to make it comply. We are only aware of limited research on this subject. The problem resembles a bankruptcy game, which is well studied, but the usual solutions there treat all agents equally, whereas in supply chains some agents have more time in control than others. Variation of delay increases approximately as the square root of the number of days in control. Hence some weighted version of cost allocation needs to be applied. This is a good subject for more consideration.

\section{Discussion and conclusions}

The growth and concentration in maritime transport due to multi-partner carrier alliances has been a mixed blessing for a crucial worldwide industry. Carrier alliances have led to greater diversity in the market as a whole with less product differentiation but with fewer carriers offering distinctly different products (Murphy, 2015). Diluted 
sailing schedules, bottlenecks and port congestion problems have evoked much concern by shippers over service levels from most carriers. According to Drewry Supply Chain Advisors, the service reliability average for May 2016 was $76.0 \%$. In an era of Six Sigma standards within industry at $99 \%$, the carrier reliability at present is poor. The Global Shippers Forum, among others, has suggested a debate is needed on whether the current carrier alliances deliver real competition, or if shippers would be better served by fewer lines competing head-on (Dupin, 2015). This would most likely force ocean carriers to fill their own ships and make less frequent port calls. Ultimately it would result in infrequent service or divided carrier choice resulting in shipper negotiations with multiple carriers.

Global management consulting firms such as the Boston Consulting Group (2015) and McKinsey \& Company (2015) have suggested market-based pricing mechanisms to spur increased levels of service and generate additional revenue for Marine Terminal Operators. A market-based approach at first glance would be simple, require little information interchange, and require only bilateral exchanges of information. However, many systems requiring coordination have strong correlations between factors. In cases of correlated requirements, pricing is not effective in the short run, though in the long run an equilibrium may occur. Since demand for cargo movement is generally thought to be relatively inelastic, BCO's do not have time to await market adjustment. It would be difficult to assign responsibility for certain outcomes such as productivity and complicates vessel sharing agreements if, for example, a carrier's VSA partner has a substandard stowage center. Would the VSA pay one rate for cargo on one ship and a different rate on a subsequent ship in the same service? This would not be sustainable in the long run. Pricing also encourages suboptimal behavior for the whole complex of supply chains by rewarding most the bottleneck providers, who are then not motivated to add capacity or take operational actions to improve throughput or service performance.

Another market-based solution proposal is an exchange that shippers and intermediaries could use to see the availability of slots on a vessel, akin to an airline booking site such as Expedia or Orbitz. A pilot effort, New York Shipping Exchange (NYSHEX) https://www.nyshex.com/, was recently launched offering a transparent market for vessel slot availability with prices and on time performance statistics for individual carriers. The market would come under the jurisdiction of the Federal Maritime Commission and all rates would be filed with the Commission. Supporters of the NYSHEX idea suggest that it would provide a source of data for transportation management systems and improve supply chain efficiency. Questions surround its viability beyond a pilot effort and its vulnerability to unwanted speculation on the part of individuals seeking to profit from buying slots prior to peak seasonal shipping and selling them as capacity is constrained (Cottrill, 2015). Market based solutions suggest that the supply chain can be improved overall on the shipment and slot segment alone. Our analysis shows real supply chains are much more complex, and the optimal service is not the sum of improvements on individual segments; some sections must work sub optimally for themselves in order to achieve overall chain optimization of service.

The standard falls into the category of collective action, in Aoki's (2007) and van der Horst and van der Lugt's (2009) classification of cooperative arrangements. It is not an incentive system; nor does it require new scope of agents or management. It is clearly more than an interfirm alliance; setting the standard is a collective action, and its success 
requires more than simply determining contracts or procedures. Many firms can be induced to follow the standard because individually and through bi- or multi-lateral contracts they can reduce transaction cost and set up their own proprietary techniques for attaining it, and also coordinate on a tangible basis with other firms and alliances. They can compete on specifics, while providing a well-understood rubric for identifying the goal.

We suggest that ocean carriers through carrier alliances can look for ways to develop performance standards to their benefit and encourage alliance inclusion of downstream supply chain partners in a standard setting that all could talk about and work toward. Alliances could play an important role in coordinating and initiating the standard-setting process. Most supply chain partners would welcome some standardization of their obligations so that expectations are clear for the customer. The gap between expectations and perceptions would be reduced, leading to fewer complaints and disputes; improvements could be targeted at the aggregated class of standard service rather than on a chain-by-chain, shipment-by-shipment basis. The standards would need review and updating and most likely would require new development as technology changes.

Coordination by alliances may be difficult; ocean carriers are the tail of the chain, and unless they can start to gain customers and credence at managing the balance of the process for customers, (as do large third party logistics firms such as DHL and UPS), there would be attempts to go around standards among the carriers at the bottom seeking their own benefit or those of smaller coalitions. An international standards group similar to the Paris based International Chamber of Commerce could devise the service standards that partners should accept and work to. Then both ocean carriers and customers as well as partners could measure departure from these service standards, and could share information to track them and identify how to improve.

Additional data and targeted performance metrics may reveal specific areas where ports, regulating bodies, trucking interests and alliances can work together to implement new approaches to alleviate the root causes of port congestion and enable freight transporters to cost-effectively keep up with demand. A movement to standard service terms would not be seen as a barrier to competition, particularly if the standard setting committee were broad based. Instead, regulators would perceive that it provides a platform for conformance and for cooperation among stakeholders, and a basis for consumers to evaluate carrier and handler performance, offering transparency and promoting competition.

Our observations suggest that further policy research be performed in examining the effectiveness of standard-setting in ocean shipping as suggested in this study and those in related industries. We suggest the need for increased dialogue within the industry and with global regulators on the potential for the development of international standards. The true test of success or failure of ocean carrier alliances will be in what role they play to advance rather than to impede the growth of international commerce.

\footnotetext{
Acknowledgements

There are no additional individuals who contributed towards the article.
}

Funding

There were no additional sources of funding for this research. 
Authors' contributions

All authors read and approved the final manuscript.

Competing interests

The authors declare that they have no competing interests.

\section{Publisher's Note}

Springer Nature remains neutral with regard to jurisdictional claims in published maps and institutional affiliations.

\section{Author details}

${ }^{1}$ Global Business and Transport, State University of New York, Maritime College, Bronx, NY, USA. ${ }^{2}$ International Business and Logistics, California State University, Maritime Academy, Vallejo, CA, USA.

Received: 2 January 2018 Accepted: 5 July 2018

Published online: 23 August 2018

\section{References}

Aoki M (2007) Endogenizing institutions and institutional changes. J Inst Econ 3(1):1-31. https://doi.org/10.1017/ S1744137406000531

Bagby JW (2015) How standardization will balance sustainability goals in the transport component of energy supply chains: efficiency versus environmental safety. Transportation Journal 54(1):136-149

Boston Consulting Group. (2015) The Transformation Imperative in container Shipping: Mastering the next big wave. Report, March 19, 2015. Retrieved on February 23, 2016. https:/wwww.bcg.com/en-us/publications/2015/ transportation-travel-tourism-transformation-imperative-container-shipping.aspx

Button K, Haynes K, Stough R (1998) Flying into the future: air transport policy in the European Union. Edward Elgar, Cheltenham, UK

Cariou P (2008) Liner shipping strategies: an overview. Int J Ocean Syst Manag 1:2-13

Clark D, Kozlova V, Schaur G (2014) Supply chain uncertainty in ocean transit as a trade barrier. In: Proceedings, working paper, Department of Economics, University of Tennessee

Clarke R (1997) An analysis of the international ocean shipping conference system. Transp J Summer:17-29

Cottrill K (2015). Will NYSHEX lift container shipping service levels? Supply Chain @ MIT, posted on 10 December, Retrieved from http://supplychainmit.com/2015/12/10/will-nyshex-lift-container-

Cullinane K, Khanna M (1999) Economies of scale in large container ships. J Transp Econ Policy 33(2):185-207

Damas P (1996) The scramble for position, American Shipper, March, pp 28-39

Davies P, Kieran M (2015) Port congestion and drayage efficiency, paper presented at the METRANS international urban freight conference. Long Beach, CA

De la Torre F (1999). Airline alliances: the airline perspective, flight transportation laboratory, Massachusetts Institute of Technology, Department of Aeronautics

Doganis R (2006) The airline business, 2nd edn. Routledge, London, UK

Dupin C (2015). Global shippers' forum questions benefits of carrier alliances to shippers, American shipper, 18 November

Esper T, Williams L (2003) The value of collaborative transportation management (CTM): its relationship to CPFR and information technology. Transp J 42(4):55-65

Franc P, Van der Horst M (2010) Understanding hinterland service integration by shipping lines and terminal operators: a theoretical and empirical analysis. J Transp Geogr 18:557-566

Fransoo J, Lee C-Y (2013) Critical Role of Ocean Container Transport. Production and Operations Management 22(2): 253-268. https://doi.org/10.1111/j.1937-5956.2011.01310.x

Glave T, Joerss M, Saxon S (2014). The hidden opportunity in container shipping, McKinsey \& Company (2015), November. Retrieved from: https:/www.mckinsey.com/business-functions/strategy-and-corporate-finance/our-insights/the-hiddenopportunity-in-container-shipping

Global Shippers Forum (2015) Fourth annual report, June, p 6

Heaver T, Meersman H, Moglia F, Van De Voorde E (2000) Do mergers and alliances influence European shipping and port competition? Marit Policy Manag 27(4):363-373

Holt J. (2015). Presentation at JOC port performance conference, Newark, N.J., December 8. http://www.joc.com/portnews/us-ports/us-port-authorities-warned-be-more-judicious-mega-ship-infrastructure-prep_20151215.html

Jensen L (2015) as quoted By Raun, K.G. in, The alliances roles in the 2015 container drama, Shipping Watch. 2 February, retrieved from http://shippingwatch.com/secure/carriers/Container/article7329088.ece

Karmelic J (2010) Vessel sharing agreement. Sci J Marit Res 24(2):211-228

Lam J, Voorde E (2011) Scenario analysis for supply chain integration in container shipping. Manage Policy Manage 38(7):705-725

Landon F 2015. Shipper survey reveals customers blame megaships for unstable global container trades, Lloyd's list, 14 October. Retrieved from http://www.lloydslist.com/11/sector/containers/article470562.ece

Leach P (2015). Alliances under the microscope. 16(1):50-52

Leachman R (2008) Port and modal allocation of waterborne containerized imports from Asia to the United States. Transp Res E 44(2008):313-331

Lee CY, Song D-P (2016) Ocean container transport in global supply chains: overview and research opportunities. Transp Res B:1-33

Leiponen A (2008) Competing through cooperation: the organization of standard setting in wireless telecommunications. Manag Sci 54(11):1904-1919 
Lidinsky R (2015a). Lidinsky takes a look at box line alliances- one year on, Lloyds list, 30 September, Retrieved from http://www.lloydslist.com/11/sector/containers/article469156.ece

Lu J (2015) as quoted in Dubin,G., Gubish, M., Waldron, G.; (2015), After the gold rush, Airline Business September, V.31, n.7, 30-33

McKinsey \& Co. (2015) How to rethink pricing at container terminals. Travel Transport and Logistics, December 2015. Retrieved on January 15, 2016. https:/www.mckinsey.com/industries/travel-transport-and-logistics/our-insights/ how-to-rethink-pricing-at-container-terminals

McLean A, Biles W (2008) A simulation approach to the evaluation of operational costs and performances in liner shipping operations. In: Proceedings of the 2008 Winter simulation conference, pp 2577-2584

Meng TC (2016) Changing and growing, Ports and Harbors, January/February, pp 8-9

Merk O (2016), As the shipping world churns, alliances raise questions, wall street journal, 12 May. Retrieved from http://www.wsj.com/articles/guest-voices-as-the-shipping-world-churns-alliances-raise-questions-1463080227

Midoro R, Pitto A (2000) A critical evaluation of strategic alliances in liner shipping. Marit Policy Manag 27:31-40

Murphy A (2015), Between the lines, Lloyds list, 19 October. Retrieved from http://www.lloydlist.com/11/sector/ containers/article470561.ece

Notteboom T (2006) The time factor in liner shipping services. Marit Econ Log 8:19-39

Notteboom T (2015) How might the proposed m\&a activity in container shipping affect alliance formation? Port Economics, Newsletter

Notteboom T, Rodrigue J-P (2005) Port regionalization: towards a new phase in port development. Marit Policy Manag 32(3):297-313

Notteboom TE, Rodrique J-P (2012) The corporate geography of global container terminal operators. Marit Policy Manag 39(3):249-279

Notteboom TE, Yap WY (2012) Port competition and competitiveness. In: Tally W (ed) The Blackwell companion to maritime economics. Wiley-Blackwell, Chichester, p 549-570

NY/NJ Port Authority, (2015). Final report, port performance task force, June

Panayides P, Wiedmer R (2011) Strategic alliances in container liner shipping. Res Transp Econ 32:25-38

Panayides PM, Cullinane K (2002) Competitive advantage in liner shipping: a review and research agenda. Int J Marit Econ 4(3):189-209

Rosenkopf L, Tushman M (1998) The coevolution of community networks and technology; lessons from the flight simulation industry. Ind Corp Chang 7(2):311-346

Song DW, Panayides P (2002) A conceptual application of cooperative game theory to liner shipping strategic alliances. Marit Policy Manag 29(3):285-301

Tseng PH, Liao CH (2015) Supply chain integration, information technology, market orientation and firm performance in container shipping firms. Int J Logist Manag 26(1):82-106

United Nations Conference on Trade \& Development (UNCTAD) (2015) Review of Maritime Transport, p 39

van der Horst M, van der Lugt L (2009) Coordination in railway hinterland chains: an institutional analysis. International Association of Maritime Economists, 24-26 June, Copenhagen, Denmark

van der Horst M, van der Lugt L (2011) Coordination mechanisms in improving hinterland accessibility: empirical analysis in the port of Rotterdam. Marit Policy Manag 38(4):415-435. https://doi.org/10.1080/03088839.2011.588257

van der Horst M, van der Lugt L (2014) An institutional analysis of coordination in liberalized port-related railway chains: an application to the port of Rotterdam. Transp Rev 34(1):68-85. https://doi.org/10.1080/01441647.2013. 874379

Wang DH (2014a) Ocean shipping deregulation restructures the liner shipping industry. Marit Policy Manag 41(1):97-111 Weber K (2005) Travelers' perceptions of airline alliance benefits and performance. J Travel Res 43(3):257-265

\section{Submit your manuscript to a SpringerOpen ${ }^{\circ}$ journal and benefit from:}

- Convenient online submission

- Rigorous peer review

- Open access: articles freely available online

- High visibility within the field

- Retaining the copyright to your article 